\title{
One of the Countries That Turkey Models: Finland Secondary Education Social Studies Curriculum
}

\author{
Yaşar Kop $^{1}$ \\ ${ }^{1}$ Dept. of Social Studies, Faculty of Education, Kafkas University, Kars, Turkey \\ Correspondence: Yaşar Kop, Kafkas Üniversitesi, Eğitim Fakütesi, Sosyal Bilgiler Öğretmenliği Bölümü, 36100 \\ Kars, Turkey. Tel: 90-532-513-4582. E-mail: yasarkop@gmail.com
}

Received: August 4, 2016

doi:10.5539/ies.v10n2p15

\author{
Accepted: September 15, $2016 \quad$ Online Published: January 30, 2017 \\ URL: http://dx.doi.org/10.5539/ies.v10n2p15
}

\begin{abstract}
Teaching of social studies has basis of education dynamism that governments maintain to raise qualified and efficient citizens. That's why; being examined programs in question has importance for the global citizen concept which comes up with globalization. Therefore, how to be raised efficient citizens who build both governments' and world's future is going to be determined. Turkey has chosen some countries as guides in education to keep up with globalization world standards. One of these countries is Finland. "Core Program" which is in force in the country is has been taken as basis in this study in which secondary education Social Studies curriculum occupying an important place in Finland education system is reviewed. Geographical and historical features and education system of the country are described (have been depicted shortly so as to ensure to be understood better the program in question. When we look at Finland education system in general, it can be said the tradition of sublimating the common objectives in Finland culture slows down the reflection of liability to bring individuality forward on implementation. School programs aims to equip the youth with knowledge and skills they will need in the social life naturally as well as aiming to transmit the basic values of Finland culture to the students. Equality of entire community is taken into consideration while doing this. Concerning available general program, it has been confirmed that general goals of "secondary education Social Studies curriculum" are to equip learners with talent to analyze current events efficiently and critically and prepare them to join social activities.
\end{abstract}

Keywords: social studies curriculum, secondary, Finland

\section{Introduction}

Today, technology develops/ascends increasingly. It is necessary to follow the technology in any condition. To do this competitive superiority must be obtained that is ensured with knowledge and skill. Entire world thought this achievement would be gained through university education. However, it is required to revising elementary and secondary education before university education. Because, as Japanese said education is development of citizens of an entire country and fuel of civilization (Can, 1994).

In fact, elementary education has an indisputable place in education. Because, elementary education is true equality of opportunity and chance for the children. That's why it is called "basic education". Right of elementary education is guaranteed under almost all constitutions of the countries as specified in Article 42 of Constitution of Republic of Turkey and it is underlined that this stage of education is compulsory and free of charge for everyone without any exception (MEB, 1982).

Scientists and economists suggest that the investments made for the purpose of education have two yields, one of which is societal and other one is personal. The calculations performed in 58 countries have indicated that societal yield of education descends as its stage rises. That is, while the stage which ensures the highest societal yield and the lowest personal yield is elementary school, the stage which ensures the lowest societal yield and highest personal yield on the contrary is higher education (Aslan, 1999). As can be understood, yield of elementary school is completely oriented towards the society. Therefore, elementary education is equal to existence of a society.

Throughout the history, the countries have affected each other in many aspects. One of these effect fields is history. It is obvious that today education lies behind some countries' rapid growth and becoming one of the 
most developed countries of the world. Therefore, it will be helpful to solve problems of the country by reviewing the developed countries in terms of education, how they find solutions to similar problems, if any (Semerci, 2000).

As Turkey also models some countries itself on many fields, it has chosen some countries as guides education. Country education politics aiming to raise individuals who can solve problems in globalizing world, take reasonable decisions have been initially followed. One of these is Finland.

When we review Finland education system as a necessity of our subject, it will possible to see that sublimating the collective objectives in Finland culture is preferred to individualism. Curriculums aims to teach basic values of Finland society and culture to the students and it will be understood that it is planned to equip the students with knowledge and skills they will need in the social life and to ensure this with the equality of whole society.

In this study researching Social Studies curriculum of Finland secondary education, Social Studies Core Curriculum which is applied in the country has been reached from first-hand sources. Education system and general features of the country are also handled in our research as well as curriculum (its geography, history and political structure, population data and economy). Finally, with the aim of shedding light of being originated a comparative table of Turkey and Finland social studies curriculum is given.

\section{Geographical Features of the Country}

Although Finland is quite similar to other Scandinavian countries in terms of its geographical features, being from Turan race, it differs from Sweden and Norway with this and similar features. Being a Northern European country, Finland ranks the sixth in terms of size with a surface area of $337.037 \mathrm{~km}^{2}$ (Demirel, 2000).

It is surrounded by Norway in the north, Finland Sea and around 30 thousand islands in the South, Sweden in northwest, Bothnian Bay in southwest and Russian Federation in the East (Inandik, 1979). Southern of the country is completely covered by plains and lakes. There are nearly 55 thousand lakes and many rivers connecting them. The biggest lake among them is Saimaa $\left(4400 \mathrm{~km}^{2}\right)$ and biggest river is Kemi $\left(540 \mathrm{~km}^{2}\right)$. Forests cover nearly 70\% of the country (Inandik, 1979; Meydan Larousse, 1992).

In Finland, according to 2015 data demographically totally 5.413 .971 people live (nufusu.com, 2016). 90\% of the country populations are located in middle and south Finland. Population density is low and only 16 people fall into $\mathrm{km}^{2}$ (Gumus, 2006).

In the country whose population density is low, a small part of the country's land (9\%) was convenient for agriculture before approximately half century. Even so, main component of commerce comprised of agriculture and forestry products. In time, Finland economy has become to be known for fast-growing industry sector (Gumus, 2006, p. 20). Particularly, Finland economy went through a radical change within the last decade and modern industry sector grew rapidly (Nokia is an example of this). (Inandik, 1979, pp. 45-47, 53-58; Allnet, 2009; Türkoğlu, 1998).

\section{Finland History}

It is estimated that first settlement in Finland began around 5 thousand years ago. However, it is accepted that the Finnish people from Altaic branch of Ural-Altaic language group came to this land in A.D. 400s. However, there are two important turnings in Finland history. The first of them is that they lived under Sweden era between 1150-1809. The second stage is under the Russian Czarism which lasted short time. (1809-1917) (Marlow, 2002; Inandik, 1979; Cengiz, 2011).

Finland gained self-government on December 6, 1917 with an organized passive resistance in the late period it was under the rule of Russia Czardom as a Grand Duchy. Meanwhile, Carl Gustav Emil Mannerheim (1867-1951) won the independence war and prepared the way heading to accept Finland Constitution on July 17, 1919 (Mannerheim, 1988, XIII; Marlow, 2002).

Unsteady days came back soon after for Finland. The period between 1931-1939 might be described as the days when life of the economy left its soul in Finland. Also, Non-aligned Finland found itself in Second World War without understanding what was going on after the attack organized to Finland by Soviet Union in 1939. Finland had to fight against the Soviet Union between 1939-1944 and German in 1944-1945. As a result of the war, Finland lost around one hundred thousand of its people. Only Finland was not occupied by foreign unions among all the counties attending Second World War from European Continent and moreover Finnish democracy was not interfered (Cengiz, 2011; Meydan Larousse, 1992).

The effort of Finnish people to protect their independence resulted in rapid development of their country after the war. (Mannerheim, 1988). It might be listed among the appraisals required to be taken into consideration that 
Finland went through restructuring without receiving Marshal assistance as well as its policy which enabled it to build a reputation in the area of economy.

\section{Education System}

Preschool education, elementary education and secondary education in Finland are arranged in the frame of objectives and fundamental curriculum set in the laws, conditions concerning compulsory and free education for everyone, occupational education and academic training are specified in 1919 Constitution. Education language is Finnish and Swedish which are the official languages of the country. There are also schools providing education in English, German in the big cities where foreigners live densely particularly in Helsinki. (Statistics Finland, 2016). Nearly five per cent of the students receiving education in second half of elementary and secondary education study at the schools where language medium of instruction is Swedish.

Both two language groups have education institutions at higher education level (MEB-SGB, 2016). At least two foreign languages are taught in Finland apart from mother tongue, which has proven to attach the deserved importance to language. First foreign language teaching begins at $3^{\text {rd }}$ grade.

Education is under the responsibility of Ministry of Education in Finland. National Education Committee works to develop objectives, contents and methods of education for elementary, secondary and adult education together with Ministry. In addition to this, each of six Finland states has one Ministry of Education and Culture which is concerned with these subjects. Local management is under the responsibility of local officers-municipalities who undertake very substantial roles with respect to providing education (MEC, 2013; YÖK, 2009).

According to Finnish educators, paying attention to students who are weak and fall behind leads to better results in the society as compared to encouraging the talented children to show higher performance. The main idea in here is established on the principle that smarter children will assist their friends who fall behind them without preventing their own developments. It should be especially emphasized that average class size which is considered to be parallel to achievement is not small in Finland. It is also required to underline that there isn't any private education institution/private classroom in Finland-except for international schools-. With this judgment in mind, it will be seen that 90 per cent of the education institutions are state schools. It can be said that adopting a productive and also authoritarian education model which does not take the students under pressure and which gives the pleasure of learning and researching became influential in school's being a lovable institution in Finland. As Frassinelli (2006) and Finnish authorities indicate that it is useful to answer how successful the Fin education system is "teachers, teachers and again teachers."

From their birth to age of 6 , children go to nurseries [kindersarten] or smaller family nursery groups in private nurseries which demand a reasonable price in line with income level of each family. Upto 4 children are cared in a house in the scope of group. Since 2001, all 6-years-old children have the right to receive free pre-school education (MEBDİGM, 2006; MEB-SGB, 2016; Erginer, 2006).

Basic Education Act (628/1998) which is in effect since January 1, 1999 do not divide the comprehensive schools into two stages as first half and second half. This act specifies that compulsory education lasts only nine years and while education is delivered by classroom teacher within the first 6 years, it must be delivered by field teachers in the last three years (MEB-SGB, 2016). The school which is arranged according to Basic Education Act and which corresponds to elementary schools in Turkey is called Peruskoulu/Grundskola [comprehensive/multi-purpose school]. The basic education carried out in comprehensive or multi-purpose schools include the group between 7-16 years old. There are 580.000 students in compulsory education as of 2003. Despite this high number of students, the rate of completing compulsory education country-wide is $99.7 \%$ and the lowest rate of dropping the school belongs to Finland. A school year comprises of 190 class days, education begins in August and continue until beginning of June. Education and any type of education material is free of charge. Also free lunch is delivered at school and the students residing $5 \mathrm{~km}$ away from the school are given the opportunity to benefit from mass transportation vehicles free of charge (Marlow, 2002; Pala, 2008; MEBDIGGM, 2006; MEB-SGB, 2016; Erginer, 2006).

It is not obligatory to attend school in 7-16 age education groups. Students are also free to gain similar knowledge and skills from some other sources. Despite this, almost all students prefer to go to multi-purpose schools (MEBDIGM, 2006).

While student selection for secondary education second half is made in accordance with previous school works, it may cover the selection criteria used by occupational secondary education second half and possibly entrance and skill exams. $90 \%$ of the students continue their education right after basic education (Marlow, 2002).

Second stage secondary education programs since 1982 provide general education of three years to students 
between 16-19 years old. During this term, students are applied polytechnic programs and programs which prepare the students for the universities as well as basic education programs (MEBDIGM, 2006). Although education program of second grade education is determined as three years, students can complete this education in 2 years or 4 years (MEB-SGB, 2016).

There are at least 75 classes in high school program and $45-49$ of them are compulsory classes. At the end of three years high school education, matriculation examination is taken country-wide. This examination is given twice in spring and autumn by Matriculation Examination Commission assigned by Ministry of Education. The students who complete the high school are given high school diploma before entering matriculation examination. Matriculation examinations are considered a part of high school education and majority of the students take this examination. Because matriculation certificate is obligatory for application to university and entrance examinations (Marlow, 2002; YÖK, 2009; Erginer, 2006).

There are occupational high schools in the scope of second grade secondary education programs. The objective in occupational education given in seventy give different fields is to ensure that the students gain the skills required in business life. Education and lunches are for free in high schools and occupational schools, the students are required to buy the course books. It is also seen that students are given education scholarship and credit (MEBDİGM, 2006; Demirel, 2000).

Higher education includes polytechnic schools started to be established as of 1991 apart from universities. Polytechnic schools were formed occupational schools in order to meet the demand for higher education (www.yok.gov.tr/egitim/raporlar/giris_sinavi/finlandiya). Universities provide academic training and carry out scientific researches. The terms of the educations differ according to their degrees and vary between 3 to 6 years. Polytechnic schools are the places which provide applied training to youngsters and adults already working. Term of service is approximately between 3.5 and 4 years (Marlow, 2002; Erginer, 2006; MEBDİGM, 2006).

State provides financial support to university students who are Finland citizens so that they could maintain their education. Support pack comprises of education scholarship, rental aid and education credit. According to statistics published in 2007, the number of total students studying at universities in 2005 is 176.061 and number of graduates is 19.176 (Statistics Finland, 2016).

\section{General Features of the Social Studies Educational Program}

In this study which researches Finland Secondary Education Social Studies Program, Social Studies Core Curriculum was accessed as a result of literal translations made from official website of Country's Ministry of Education (www.minedu.fi), official studies of Ministry of Education (National Core Curriculum for Basic Education-2004 and National Core Curriculum for Upper Secondary Schools-2003) and EURYDICE which is European education information web. There is basic information which all students need to know. However, it might sometimes be discussed what this information are and who will determine such information. Core curriculum, which is a program development theory, means determining basic/core information and skills to be given to all the students and giving them to the students (Oncul, 2000).

As specified in judgment of modifying the approaches in education programs of Ministry of National Education of Republic of Turkey, various arrangements have been made in many developed countries recently and constructionist approach was used in process of preparing the program. Especially, programs were prepared and commenced to be applied in the light of constructionist approach in countries such as United States of America, Australia, New Zelland and Finland. Turkey took above-mentioned countries as example, and therefore Finland (see Appendix, Table 1-2). Even according to YOPID Report (2005), the impact of above mentioned countries formed a synergy and arranged the new elementary education programs as well as EU harmonization works and globalization. [It is known that mentioned countries obtained positive results in line with structuralism and in the scope of economy (Akpinar \& Aydin, 2007)]. As seen in Finland example which is followed closely, constructionist theory attracts the attention of educators for enabling the students to skills of learning by doing-experiencing, solving problem and making decision. The fact that the Social Studies curriculum prepared in line with this approach was arranged as to enable the students to transfer the knowledge they have acquired to solving problems and making decisions made this course more successful (Önal \& Kaya, 2006).

Social Studies curriculum used today in $7^{\text {th }}-9^{\text {th }}$ grades in elementary education in Finland was published in 2004 and Social Studies curriculum applied in $10^{\text {th }}-12^{\text {th }}$ grade in secondary education in Finland was published in 2003. Since published Social Studies curriculum was given in the form of core curriculum, it comprises of ten pages. Given in both levels, Social Studies course is involved within compulsory courses.

The overall purpose of Social Studies education as included in core curriculum is to ensure that students become 
active and responsible individuals within the society. The specific objective of teaching this course is to support the students to grow as tolerant and democratic citizens and to give them the opportunities to take social actions and perform democratic implementations.

As for the Social Studies education provided between tenth and twelfth grades of secondary education, it is aimed to equip the students with the skill to examine the current incidents effectively and critically and prepare them to attend to the social activities. With regards to this course; politics and society, economy, citizenship and society, Europeanisms and European Union courses are provided between tenth and twelfth grades in the scope of social sciences.

In line with the instructions specified by Ministry of Education of Finland, the teachers giving Social Studies course are entitled to determine their own course-books and education equipment and decide independently on education methods like the other branch teachers (Erginer, 2006).

\section{Secondary Education Social Studies Program}

Social Studies education on this level will stimulate the students' knowledge concerning the society which surrounds them. Societal structure and the fundamental items constituting this structure, power, economy and impact tools will be handled from the perspective of Finland, Europe and world. Social Studies are based on different social sciences-which are history, geography, economy, sociology, anthropology, psychology, philosophy and politics for the purpose of realizing societal existence of the individual- and content of law. This course will equip the students with the skill to review up-to-date incidents with an effective and critical eye [Basic objective of social studies is to help the students to make reasonable and correct decisions and behave like a responsible citizen. Therefore, thinking skills such as critical thinking, solving problems, creative thinking is among the basic objectives of Social Studies education].

Social Studies education is based on socio-ethical values and active citizenship such as justice, equality, social responsibility, respecting human rights, significance of working and entrepreneurship.

\subsection{Learning Outputs}

It is aimed to enable the students to gain the following in general through Social Studies education at secondary education level;

- To understand the nature of society as a result of historical development;

- Being familiar with the foundations and practices of Finland's social system and economy and be able to place these in European and international contexts;

- To command key social and economic concepts;

- Being aware of the opportunities to influence and participate in a civil society and also knowhow to use these;

- Being capable of acquiring current information from different sources and of assessing verbal, visual and statistical information critically;

- Being capable of forming justified personal views of controversial social and economic issues that are bound to values;

- To obtain capabilities to build a conception of society based on responsibility, tolerance and respect for equality.

\subsection{Content}

A multi-disciplinary form of content was created as mentioned above in preparation Secondary Education Social Studies curriculum. From the said content, it was attempted to create an inter-disciplinary structure from the courses which gained presence among compulsory and specialization disciplines, learning fields and acquisitions of which are given below. The compulsory courses said to form the content of Social Studies Curriculum in core curriculum and learning field(s) and acquisitions of the same are as follows:

Politics and Society: Students in here will recognize political and social systems focusing on Finland society and analyze Finland society utilizing concepts of politics, social psychology and sociology. Development of basic societal structure, power and impact tools constitute the significant issues. The acquisitions the students are expected to obtain might be listed as follows: • to understand the basic structures of Finnish society; • being familiar with basic civil rights and the citizen's means of and opportunities to influence society; $\bullet$ to adopt a balanced and analytical approach to society; $\bullet$ being familiar with the foundations of the welfare society. 
There are following learning fields and contents under these basic titles:

1) Learning area

The development of Finnish society; • the population structure of Finland; • construction of the welfare state; • possibilities of the welfare state.

2) Learning area

Power; $\bullet$ power as a concept and ways of exercising power; $\bullet$ political systems.

3) Learning area

Means of influence; $\bullet$ democracy and civil society; • global influence; • challenges to the exercise of influence.

4) Learning area

The rule of law and security systems; • fundamental rights; • judicial power and law-enforcement authority; • security policy and changing threat scenarios.

Social policy; $\bullet$ purpose, roles and forms.

Economics: In this course, students will be guided so that they could understand principles of economic activity. Economics is taken as basis. Issues related to micro and macro economy are handled from the perspective of consumers, business men and states. Students will be aware of economic life through different statistics and other sources. Students are expected to gain following acquisitions: - to acquaint themselves with the most important foundations, concepts and theories of the national economy; - to acquaint themselves with the current state and future prospects of the Finnish and international economies; - to obtain skills to make every day economic decisions and also examine economic issues from an ethical point of view; - being aware of the significance of work and entrepreneurship to the national economy.

The learning fields and their contents as provided in core curriculum are as follows:

1) Learning area

Finns' sources of livelihood; • primary production; • technology and industrialization; • the service society.

2) Learning area

Economic activity and business enterprises; $\bullet$ basic economic concepts; $\bullet$ supply, demand and equilibrium as the foundations of the market economy; • competition and its forms; • business activities and consumers.

3) Learning area

Economic fluctuations and disturbances; • economic growth; • Keynesianism and monetarism as alternative solutions to economic disturbances.

4) Learning area

Monetary policy and the financial market; $\bullet$ market deregulation; $\bullet$ structure of the financial market; $\bullet$ monetary policy and interest.

\section{5) Learning area}

Public economy and economic policy; • taxation and fiscal policy; • politics and market forces; • incomes policy.

6) Learning area

Finland in international trade; • the internationalizing economy and Finland; • effects of globalization.

7) Learning area

Future prospects of the Finnish economy; • risk factors, opportunities and limits of growth.

The specialization courses said to form the content of Social Studies Curriculum in core curriculum and learning field(s) and acquisitions of the same are as follows:

Citizens and law: Students will be provided with basic information concerning Finland law and taught defending their rights and learn basic legal procedures. The objective is to gain the students the following: $\bullet$ to learn the basic facts of Finnish law and its key principles; $\bullet$ to obtain basic knowledge of the Finnish judiciary system and the international courts that are important to citizens; $\bullet$ to learn to attend to the most common legal matters independently; $\bullet$ to know their rights, benefits and duties as citizens, employees and consumers; $\bullet$ being capable of finding and learn to use the main sources of legal information; $\bullet$ to want to act fairly and lawfully.

Learning fields in line with these objectives and their contents might be listed as follows: 


\section{1) Learning area}

The basics of law; $\bullet$ Finland's legal history; $\bullet$ the law and the legal system; $\bullet$ basic concepts; $\bullet$ acquisition of legal information.

\section{2) Learning area}

Citizens' basic legal transactions; $\cdot$ family law; $・$ labour law; $\bullet$ consumer protection; $・$ debts, guaranty and insolvency; $\bullet$ housing; $\bullet$ appeals against the authorities' decisions.

\section{3) Learning area}

Criminal and procedural law; $\bullet$ legal proceedings and alternative procedures; $\bullet$ punishments; $\bullet$ international law and appeal procedures.

Europeanism and European Union: The students will be learning proceedings of European Union and significance of European integration in terms of citizens and will be encouraged to participate in up-to-date discussions with regards to European Union (EU). Students are expected to gain the following acquisitions: • to obtain diverse and in-depth information about the European Union and its operations; • learn to function as citizens of the European Union; • being familiar with the advantages and disadvantages, opportunities and threats involved inEuropean integration; $\bullet$ being able to acquire comparative information about the European Union and its citizens; $\bullet$ to understand the effects of European integration in terms of their own lives and of theFinnish political system.

Learning fields and their contents in the light of above-mentioned information are as follows:

\section{1) Learning area}

European identity; $\bullet$ common European values; $\bullet$ EU citizenship.

\section{2) Learning area}

Exercising influence and power in the European Union; • the European Union's decision-making system; • Finns as part of the European Union's decision-making system; • different members.

\section{3) Learning area}

Regional effects of the European Union; • young people's opportunities to study and work within the EU; • the Union of the Regions from the citizens' perspective.

\section{4) Learning area}

Challenges to the European Union; $\bullet$ EU enlargement; $\bullet$ common security policy; $\bullet$ EU and global systems.

\section{Learning-Teaching Process}

Being still in effect, social studies teaching curriculum have the characteristics of being a core curriculum. Therefore, while objective and content are given in general terms, no explanation is made with respect to teaching-learning process.

\subsection{Evaluation Aspect}

Evaluation is generally a continuous part of daily school life and each student gets at least one report in a year. In addition to this, at least one interim report can be given in a school year. Success is evaluated by both consistently and exams teachers carry out. A certificate is given to students who complete 9 years of extensive school life. An additional document is presented to students finishing 10th year which is optional. The situation in private can be expressed.

Learning concept and mass information concept affect the students in many aspects. The basic theory in formation new national main curriculum is social-constructivist. During teaching process of this curriculum which is designed in the frame of constructivism approach and therefore evaluating the learnt things in social sciences, attention will be paid to students' understanding of subject field and basic concepts in the content, explaining their knowledge in a structured manner, making critical evaluations and interpreting social events, oral, numerical and graphical information presented in different forms. These competences will be evaluated using different tests or alternative measuring methods throughout the course process. Teachers are also recommended to use various methods and techniques during course. As a requirement of constructivism, it is emphasized that alternative measuring-evaluating tools will be used in core curriculum. Therefore, student is recommended an active role that asks questions, forms problems, solves problems, attempts activities to reveal and evaluate the information required like a scientist and forms their own cognitive structure through activities rather than a role that listens, make researches, practices and answers the questions (www.iogm.meb.gov.tr). 
Also, according to EURYDICE which is the European education information net and National Basic Education Core Curriculum (2004), the students are expected to gain the following acquisitions so as to be considered successful on Social Studies courses:

- To defend their own thoughts with respect to social issues,

- To interpret the information in media, statistics and graphic presentations through a critical eye

- To be able to generate alternatives to decisions or solutions in social and economic issues and compare the results of the same,

- $\quad$ To understand the ethical questions in social and economic activities.

The students are evaluated in terms of development of information, skill, attitude and behaviors with respect to objectives/acquisitions of the course apart from certain performance indicators. Oral evaluation is used effectively in Finland together with written evaluation. As put by Erginer (2006, p. 11), students' studies and developments at school are taken into consideration in such evaluation.

\section{Discussion and Conclusion}

All the conditions required for education and training in Finland maintain their existence in law and institutions pertaining to education as attempted to be expressed in field literature. One of the reasons for presence is people's responsibility to learn undoubtedly. The schools and other institutions undertaking this work were paid attention to be distributed equally within the borders of entire country through equality of education and training and this situation took their place required in the laws (Demirel, 2000). From this point of view, the final objective of Finnish education and training policy could be said to be based on continuing and life-long education principle. A Finnish citizen includes himself/herself in circle of education and training regardless of his/her age. In other words, both state and local institutions have undertaken the responsibilities related to educating not only the children but also the adults and have not restricted the dimension of the education in this field with basic education and have attempted to make it high level.

In the light of general information given above, the overall objective of social studies education in Finland is to raise the students as citizens who have an active and responsible role within the society. In parallel with this, it is among the objectives of social studies education to raise the students as persons/citizens who are compatible, independent, productive, able to establish positive/efficient with their immediate and distant surrounding.

Social studies education in the country is focused on the subjects related to Finland and European Union. However, there is not information in the curriculum with respect to ordering and formatting the content. Also, considering the existing data, it might be said expanding environment and cyclical program approaches were used in ordering of the content and interdisciplinary and multidisciplinary program approaches were used in formatting.

All of these are made in the basis of constructivist theory and especially the importance of problem solving is mentioned. Moreover individual learning plans for students are prepared and working programs for process are regulated. Besides them, home- school cooperation is given prominence. The teachers of these courses have right to choose their own textbooks and materials. They are taken into consideration to both student behaviors and works in the school in assessment process. In addition teachers benefit from the oral assessment. They make emphasis on other evaluation techniques related to the theory of constructivism (Öztürk \& Deveci, 2011).

It is understood that contemporary pedagogic tendencies are quite influential in shaping social studies education in Finland; however, presence strong education tradition is still felt in the schools.

\section{References}

Akpınar, B., \& Aydın, K. (2007). Türkiye ve bazı ülkelerin eğitim reformlarının karşılaştırılması. Doğu Anadolu Bölgesi Araştırmaları (pp. 82-88). Retrieved from perweb.firat.edu.tr/personel/yayinlar

Allnet. (2009). Ülkeler rehberi: Finlandiya. Retrieved from www.ulkeler.net/finlandiya.htm

Aslan, M. (1999). Cumhuriyet dönemi ilköğretim programlari ve belli başli özellikleri. Retrieved from http://dhgm.meb.gov.tr/yayimlar/dergiler/Milli_Egitim_Dergisi/144/arslan.htm

Büyük Larousse. (1986). Finlandiya. C. 7. İstanbul: Gelişim Yayınları.

Can, M. (1994). Üniversite bilim adamı ilişkisi. İzmir: T. Ö. V. Yayınları.

Cengiz, C. (2011). Finlandiya tarihi özeti. Retrieved from http://canceng.blogspot.com.tr/2011/04/finlandiyatarihi 
Demirel, Ö. (2000). Karşılaştırmalı eğitim. Ankara: Pegem A Yayınları.

Erginer, A. (2006). Avrupa Birliği eğitim sistemleri: Türkiye ile karşılaştırmalar. Ankara: Pegem Akademi Yayınları.

Finnish National Board of Education. (2004). National Core Curriculum for Basic Education (pp. 225-228). Vammala: Vammalan Kirjapaino Oy.

Finnish National Board of Education. (2004). National Core Curriculum for Upper Secondary Schools-2003. Vammala: Vammalan Kirjapaino Oy.

Frassinelli, L. (2006). Educational reform in Finland. Retrieved from http://www.msu.edu/user/frassine/pdf

Gümüş, E. (2006). Ülkeler coğrafyası (2. baskı). Ankara: Nobel Yayın Dağıtım.

Inandik, C. O. (1979). İskandinavya ülkeleri. Erzurum.

M.E.B. Dış İlişkiler Genel Müdürlüğü (MEBDİGM). (2006). Türkiye ve Avrupa Birliği ülkelerinin eğitim sistemleri. Ankara: Kalkan Matbaacilık.

Mannerheim, C. G. E. (1988). Finlandiya Mareşali Mannerheim: Anılar. M. Obuz (Çev.), Ankara: Kırali Matbaacilik.

Marlow, R. F. (2002). Finland. World education encyclopedia: A survey of educational systems worldwide. (2nd ed., pp. 437-449). Detroit, New York, San Diego, San Francisco, Boston, London, Munich: Gale Group/Thomson Learnig.

MEB. (1982). Milli Ĕgitim Bakanlı̆̆ mevzuat-Türkiye Cumhuriyeti Anayasası. Retrieved from http://mevzuat.meb.gov.tr/html/kanun2709-1.htm

MEB-SGB, (2016). Finland: Funding in education. Retrieved from http://sgb.meb.gov.tr/eurydice/

MEC [Ministry of Education and Culture]. (2013). Koulutus and varhaiskasvatus. Retrieved from http://www.minedu.fi./OPM/?lang=en

Meydan Larousse. (1992). Finlandiya. C. 7. İstanbul: Sabah Yayınlar1.

Nüfusu.com. (2016). Finlandiya nüfusu. Retrieved from www.nufusu.com/ulke/finlandiya-nufusu

Önal, H., \& Kaya, N. (2006). Sosyal bilgiler ders kitaplarının (4 ve 5. sınıf) değerlendirilmesi. Ballkesir Üniversitesi Sosyal Bilimler Enstitüsü Dergisi, 9(16), 21-37.

Öncül, R. (2000). Eğitim ve eğitim bilimleri sözlüğü. İstanbul: Milli Eğitim Bakanlığı Yayınları.

Öztürk, C., \& Deveci, H. (2011). Farklı ülkelerin sosyal bilgiler öğretim programlarının değerlendirilmesi. C. Öztürk (Eds.), Farklı ülkelerin sosyal bilgiler ögretim programları (pp. 1-41). Ankara: Pegem Akademi Yayınları.

Pala, N. M. (2008). PISA 2003 sonuçlarina göre ögrrenci ve sınıf özelliklerinin matematik okuryazarliğina ve problem çözmeye etkisi (Basılmamış yükssek lisans tezi). Balıkesir: Balıkesir Üniversitesi Fen Bilimleri Enstitüsü.

Semerci, N. (2000). Japonya ve Almanya eğitim sistemine genel bir bakış: Oğretmen eğitimi açısından Türkiye ile karşılaştırma. Fırat Üniversitesi Sosyal Bilimler Dergisi, 10(1), 159-168.

Statistics Finland. (2016). Education (and Browse statistics by topic). Retrieved from www.stat.fi/tup/suoluk/suoluk_koulutus_en.html on July 4, 2016

Türkoğlu, A. (1998). Karşılaştırmalı eğitim: Dünya ülkelerinden örneklerle. Adana: Baki Kitabevi.

YÖK. (2009). Eğitim raporlarl; Finlandiya. Retrieved from ww.yok.gov.tr/egitim/raporlar/giris_sinavi/finlandiya

YÖPID Raporu. (2005). Yeni ilköğretim programlarını inceleme ve değerlendirme raporu (pp. 113-149). Retrieved from http://ilkogretimonline.org.tr/vol5say $1 /$ pdf 


\section{Appendix}

In Terms of Education, Similarities between the Two Countries

Table 1. Comparison of Turkey and Finland Social Studies Education Programs-1

\begin{tabular}{|c|c|c|c|c|c|}
\hline Country & Education Level & $\begin{array}{l}\text { Basic } \\
\text { Approach }\end{array}$ & $\begin{array}{l}\text { Social Studies } \\
\text { Education } \\
\text { Approach }\end{array}$ & Program Mentality & $\begin{array}{l}\text { Categorization of the } \\
\text { content }\end{array}$ \\
\hline Finland & $\begin{array}{l}\text { 5-9 History, } \\
\text { 7-9 Social Studies, } \\
\text { 10-12. grades Social Studies, politics } \\
\text { and society, economy, citizenship and } \\
\text { law, Europeanness and European } \\
\text { Union }\end{array}$ & $\begin{array}{l}\text { Progressivism } \\
\text { Constructionist } \\
\text { Active } \\
\text { Learning }\end{array}$ & $\begin{array}{l}\text { Social Studies as } \\
\text { Social Sciences } \\
\text { and } \\
\text { Social Studies as } \\
\text { reflective } \\
\text { research field }\end{array}$ & $\begin{array}{l}\text { Inter-disciplinary and } \\
\text { multi-disciplinary }\end{array}$ & $\begin{array}{l}\text { Expanding environment } \\
\text { and cyclical program } \\
\text { approaches }\end{array}$ \\
\hline Turkey & $\begin{array}{l}\text { 1-3 } \\
\text { Within Life sciences } \\
\text { 4-7 Within social studies course }\end{array}$ & $\begin{array}{l}\text { Progressivism } \\
\text { Constructionist } \\
\text { Active } \\
\text { Learning }\end{array}$ & $\begin{array}{l}\text { Social Studies as } \\
\text { Social Sciences } \\
\text { and } \\
\text { Social Studies as } \\
\text { reflective } \\
\text { research field }\end{array}$ & $\begin{array}{l}\text { Inter-disciplinary and } \\
\text { multi-disciplinary }\end{array}$ & $\begin{array}{l}\text { Integrating expanding } \\
\text { environment and cyclical } \\
\text { program approaches }\end{array}$ \\
\hline
\end{tabular}

Table 2. Comparison of Turkey and Finland Social Studies Education Programs -2

\begin{tabular}{|c|c|c|c|c|}
\hline Country & Targets & Content & Learning-Teaching Period & Evaluation \\
\hline Finland & $\begin{array}{l}\text { To raise students as } \\
\text { responsible citizens by } \\
\text { making them acquire } \\
\text { information and skills } \\
\text { required for social life }\end{array}$ & $\begin{array}{l}\text { Course-Learning Fields } \\
\text { "Finland Society, Economic Life, } \\
\text { European Union". }\end{array}$ & $\begin{array}{l}\text { It is arranged by taking learner's } \\
\text { needs and experiences, basic } \\
\text { targets, periodical targets, } \\
\text { learning environment, point of } \\
\text { views into consideration. It is } \\
\text { student-centered and focused on } \\
\text { activity. } \\
\text { - Using comparison } \\
\text { approaches } \\
\text { - Using different resources } \\
\text { Binding other program } \\
\text { fields } \quad \text { Using various teaching } \\
\text { - } \\
\text { approaches } \\
\text { - Using gap assessment } \\
\text { standards } \\
\text { Providing all learners' } \\
\text { necessities and taking previous } \\
\text { experiences into consideration }\end{array}$ & $\begin{array}{l}\text { It will be regarded whether } \\
\text { learners have comprehensive } \\
\text { knowledge of subject area } \\
\text { and basic concepts in the } \\
\text { content and their skills of } \\
\text { expressing their knowledge in } \\
\text { a structured way, } \\
\text { Evaluating critically and } \\
\text { interpretation social features } \\
\text { presented in different forms, } \\
\text { verbal and numerical } \\
\text { graphical information } \\
\text { These qualifications are } \\
\text { tested as a result of sample } \\
\text { works, evaluation verbal or } \\
\text { visual presentations, } \\
\text { self-assessments and written } \\
\text { examinations during periods. }\end{array}$ \\
\hline Turkey & $\begin{array}{l}\text { To raise students as } \\
\text { active and responsible } \\
\text { citizens who adopt } \\
\text { democratic principles, } \\
\text { have advanced } \\
\text { thinking skills and }\end{array}$ & $\begin{array}{l}\text { Learning fields: } \\
\text { "Individual-Identity, } \\
\text { Culture-Inheritance, People, Places } \\
\text { and Environment, Production, } \\
\text { Distribution, Consumption, Science, } \\
\text { Society, Social groups, Institutions, }\end{array}$ & $\begin{array}{l}\text { A process in which the teacher is } \\
\text { guide and which is } \\
\text { learner-centred and activity } \\
\text { focused is followed. }\end{array}$ & $\begin{array}{lr}\begin{array}{l}\text { Conventional } \\
\text { techniques }\end{array} & \begin{array}{r}\text { surveying } \\
\text { (written }\end{array} \\
\text { examination) process-output } & \text { monitoring } \\
\text { evaluation, } & \text { observing }\end{array}$ \\
\hline
\end{tabular}




$\begin{array}{llll}\text { social relations, } & \text { Social Organizations, Power, } & \text { process are encouraged. } \\ \text { produce knowledge. } & \begin{array}{l}\text { Management and Society, Global } \\ \text { Relations" }\end{array}\end{array}$

\section{Copyrights}

Copyright for this article is retained by the author(s), with first publication rights granted to the journal.

This is an open-access article distributed under the terms and conditions of the Creative Commons Attribution license (http://creativecommons.org/licenses/by/4.0/). 